ISSN 0258-7122

Bangladesh J. Agril. Res. 35(3) : 525-534, September 2010

\title{
EFFECT OF HIGH TEMPERATURE STRESS ON THE PERFORMANCE OF TWELVE SWEET PEPPER GENOTYPES
}

\author{
S. R. SAHA ${ }^{1}$, M. M. HOSSAIN ${ }^{2}$, M. M. RAHMAN ${ }^{3}$ \\ C. G. KUO ${ }^{2}$ AND S. ABDULLAH ${ }^{3}$
}

\begin{abstract}
A study on heat tolerance in sweet pepper was conducted at the Asian Vegetable Research and Development Centre (AVRDC), Taiwan from December 1999 to May 2000. Experiments were carried out to investigate the influence of $29 / 23^{\circ} \mathrm{C}$ and $24 / 18^{\circ} \mathrm{C}$ stress on 12 sweet pepper genotypes on growth, development, reproductive behaviour and yield potentialities and to verify the results of the phytotron study. Performance of 12 sweet pepper genotypes was evaluated under two different temperature regimes of $24 / 18^{\circ} \mathrm{C}$ and $29 / 23^{\circ} \mathrm{C}$ in the phytotron. Plant height was found higher at $29 / 23^{\circ} \mathrm{C}$ compared to $24 / 18^{\circ} \mathrm{C}$. High temperature reduced percent fruit set as well as size of fruits. Individual fruit weight was higher (7.44-125.00 g) when grown at $24 / 18^{\circ} \mathrm{C}$ and lower (5.35-103.80 g) at $29 / 23^{\circ} \mathrm{C}$. Out of 12 genotypes, SP00l, SP002, SP004, and SP012 performed poor in respect of per plant yield at higher temperature compared to the lower temperature. So, these four genotypes were considered to be heat sensitive than the others. Leaf proline content of the sensitive genotypes decreased under the high temperature conditions and the heat tolerant lines produced higher amount of proline indicating the role of proline in expressing the heat tolerant capability of sweet pepper genotypes concerned.
\end{abstract}

Keywords : High temperature stress, performance, sweet pepper.

\section{Introduction}

Sweet Pepper is a high valued crop in Bangladesh. Peppers are grown as an annual crop in temperate regions. The optimum temperature favourable for growth of sweet pepper ranges between 20 and $25^{\circ} \mathrm{C}$. When temperature falls below $15^{\circ} \mathrm{C}$ or exceeds $32^{\circ} \mathrm{C}$, growth is usually retarded and yield decreases. Heat stress is a major factor influencing the productivity and adaptation of wild and cultivated plants. Bell pepper is not an established crop anywhere in the tropical lowlands and it needs to go through a whole process of tropicalization. When large fruited bell peppers are exposed to environmental stresses during the flowering and fruiting period, abscission of flowers and flower buds may occur (Cochran, 1936). This loss of reproductive structures can result in serious yield

\footnotetext{
${ }^{1}$ Senior Scientific Officer, Plant Physiology Section, HRC, Bangladesh Agricultural Research Institute (BARI), Gazipur, ${ }^{2 \& 3}$ Professor, Dept. of Horticulture, Bangabandhu Sheikh Mujibur Rahman Agricultural University (BSMRAU), Gazipur, ${ }^{4}$ Plant Physiologist, AVRDC, Taiwan, ${ }^{5}$ Scientific Officer, TCRC, Bangladesh Agricultural Research Institute (BARI), Gazipur, Bangladesh.
} 
decrease, and constitutes a major risk factor in pepper production. Although the abscission can be caused by several factors, such as extremes of temperature, lack of moisture or low light conditions, high temperature appears to be the most common cause (Cochran, 1936). High temperature has an adverse effect on fruitset (Dorland and Went, 1947) in bell pepper. Poor fruit-set was believed to be one of the major barriers to the tropical adaptation of bell pepper. Song et al. (1976) observed decreased fruit-set in pepper as temperatures were raised from $18 / 13^{\circ}$ to $23 / 18^{\circ}$ and $33 / 28^{\circ} \mathrm{C}$.

Bell peppers can also be grown during winter season in Bangladesh but fruitset percentage is low since the crop is mainly developed for temperate region. So, genotypes with heat stress tolerant capability may be grown successfully under Bangladesh situation following specific cultural practices which may help improve the fruit-set percentage along with less infestation of insect-pest and diseases. The above discussion indicates that the effects of high temperature on the growth and reproductive behaviour of sweet peppers are to be studied with the new materials of AVRDC to proceed on for the development of suitable variety for tropical condition like Bangladesh. Therefore, the present investigation was undertaken to investigate the vegetative growth, reproductive behaviour and proline content of leaves of the bell pepper genotypes as affected by high temperature

\section{Materials and Method}

An investigation was carried out at the Asian Vegetable Research and Development Center (AVRDC), Taiwan to observe the performance of twelve AVRDC accessions and breeding lines of sweet pepper at different temperature regimes during the period from December 1999 to Mid-May 2000. To minimize tobamoviruses seed infection, seeds were soaked in a $10 \%(\mathrm{w} / \mathrm{v})$ solution of trisodium phosphate (TSP) for 30 minutes and then transferred them to a same fresh solution for two hours and then rinsed in running water for 45 minutes.

The seeds were sown on 10 December 1999 in 70-cell seedling trays with sowing medium in green house. The sowing medium used in the present study was $70 \%$ peat-moss and $30 \%$ coarse vermiculite. Two seeds were sown in each cell at a depth of $1 \mathrm{~cm}$ and three days after germination when first true leaf appeared, one seedling was thinned out keeping the good one intact. Before transferring, the seedlings were hardened by exposing them to direct sunlight for 4-5 days. After hardening, the seedlings were transferred to pots of $17 \mathrm{~cm}$ height and $14.5 \mathrm{~cm}$ diameter. The pots were filled up with AVRDC potting mixture, which was prepared by mixing soil, compost, and sand in the ratio of 3:1:1. The potting mixture was autoclaved at $120^{\circ} \mathrm{C}$ for 30 minutes for sterilization. 
After one week of transplanting the seedlings in the larger pots, they were placed in two walk-in plant growth chambers (phytotron) one maintaining $24 / 18^{\circ} \mathrm{C}$ and the $29 / 23^{\circ} \mathrm{C}$ day/night temperatures, respectively. In both types of growth chambers, a constant 14 hours light conditions and 10 hours dark conditions were maintained throughout the study period. Photosynthetically active radiation (PAR) in both the growth chambers varied from 350-400 $\mu \mathrm{molm}^{-2} \mathrm{~S}^{-1}$ as measured at the top of the canopy with a LI-COR (Lincoln, Nebraska, USA) model 1903 quantum flux sensor. The radiation sources consisted of cool white fluorescent (CWF) lamps and general incandescent lamps. The relative humidity inside the chamber was around $65 \pm 5 \%$. Carbon dioxide levels were approximately $350 \mathrm{gm}^{-3}$.

Two separate single factor experiments were conducted. The randomized complete block design was used. Each experiment was conducted in phytotron.

Fruits of sweet pepper were harvested when reached full size of edible maturity depending on the germplasm and became firm but before turning colour (Yellow, Orange or Red) as per Berke et al. (1999).

The different morphological, physiological and yield and yield contributing characters of the genotypes were recorded as follows: Plant height $(\mathrm{cm})$, percent fruit set, fruits per plant, individual fruit weight (g), yield per plant (g), fruit length (mm), fruit diameter ( $\mathrm{mm})$.

Proline estimation : After three weeks of growth in the growth chamber, young leaves $\left(2^{\text {nd }}\right.$ and $3^{\text {rd }}$ leaf) were used for proline estimation following the methods developed by Troll and Lindsley (1955).

The data recorded on different parameters were analyzed statistically with the help of computer 'MSTAT' program. The difference between treatment means were compared by Duncan's Multiple Range Test (Gomez and Gomez, 1984) for interpretation of results.

\section{Results and Discussion}

Plant height : Plant height of different genotypes significantly differed at different growth stages. The stages of growth were 30,60, and 90 days after transplanting and at final harvest. Plant height ranged from 41.33 to $71.62 \mathrm{~cm}$ at $24^{\circ} / 18^{\circ} \mathrm{C}$ and $53.00 \mathrm{~cm}$ to $84.33 \mathrm{~cm}$ at $29^{\circ} / 23^{\circ} \mathrm{C}$ temperature. The growth rate pertaining to the plant height was found to be low at 60 and 90 days after transplanting under both the low and high temperature conditions and plants attained higher growth at high temperature than low temperature (Fig.1). Genotypic differences came out regarding height of plants when pot plants were grown under $24 / 18^{\circ} \mathrm{C}$ as well as $29 / 23^{\circ} \mathrm{C}$ temperature, respectively, in the phytotron (Fig. 2). The plant height of SP006 was the highest $(71.67 \mathrm{~cm})$ at low 
temperature and SP00l was the lowest $(41.33 \mathrm{~cm})$. At high temperature of $29 / 23^{\circ} \mathrm{C}$, the plant height of 12 sweet pepper accessions ranged from $53.00 \mathrm{~cm}$ in $\mathrm{SP} 001$ to $84.33 \mathrm{~cm}$ in 5P002. The plant height recorded in this investigation under low and high temperature conditions implied that at higher temperature of $29 / 23^{\circ} \mathrm{C}$, all the genotypes had the tendency to grow vertically with much more rate than the plants raised under the comparatively low temperature of $24 / 18^{\circ} \mathrm{C}$ (Fig. 2). Bakker and Uffelen (1998) stated that plant height was significantly correlated to 24-h mean temperature as well as day/night temperature amplitude. Rylski and Spigelman (1986b) obtained plant height of sweet pepper lower in the field condition $(66.2 \mathrm{~cm})$ and high in the screen house where temperature was higher than open field $(95.1 \mathrm{~cm})$.

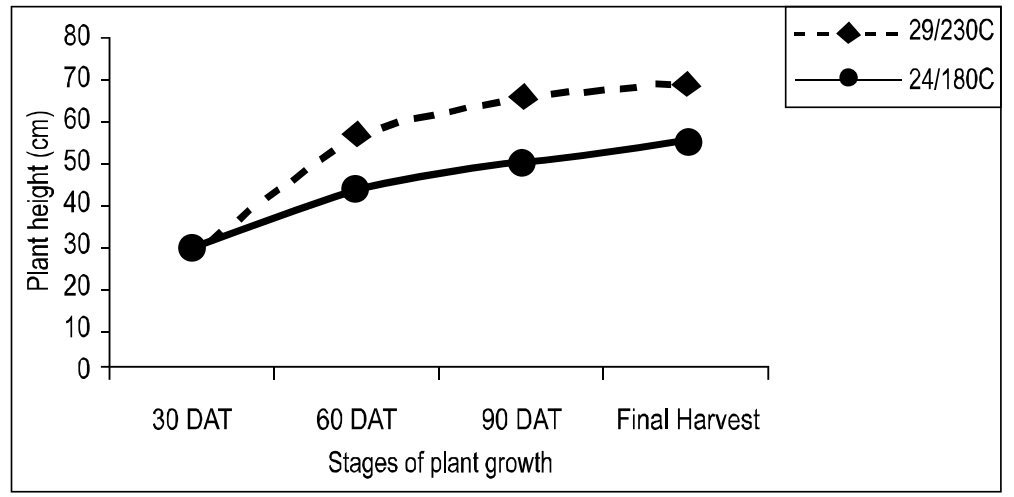

Fig. 1. Plant height of sweet pepper due to temperature effect at different growth stages.

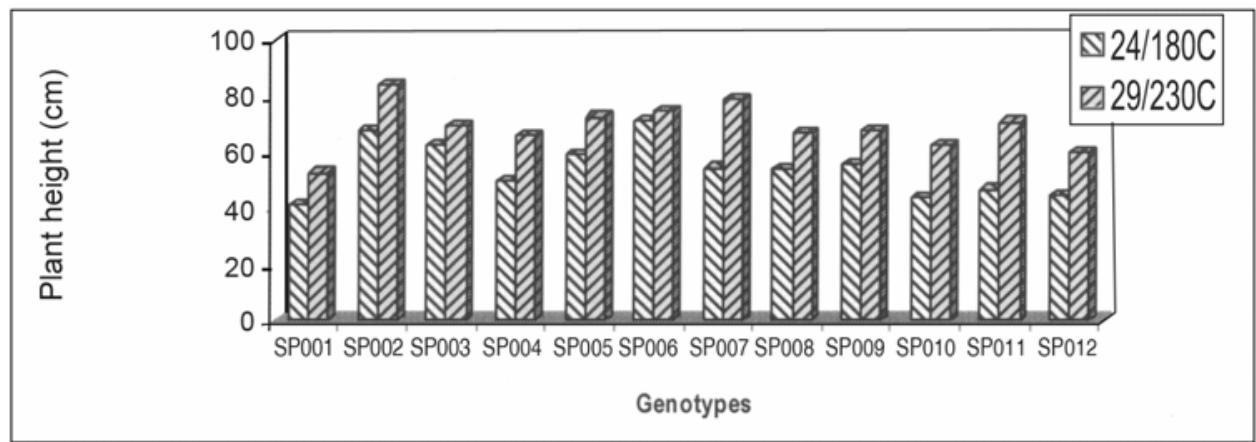

Fig. 2. Genotypic difference in plant height at final harvest due to high and low temperature,

Percent fruit set : Percent fruit set varied from 14.63 to 56.17 at $24^{\circ} / 18^{\circ} \mathrm{C}$ being the lowest in SP011 and the highest in SP002. Under high temperature condition, it was $48.86 \%$ in SP002 and $10.47 \%$ in SP00l. Percent fruit set was around 20 in case of four germplasms out of twelve (Table 1). Fifty percent 
genotypes set fruits in the range from 21.87 to 28.15 . It could be observed that the percent fruit set of all the genotypes were lower at higher temperature and higher at comparatively low temperature. Rylski and Spigelman (1982) found $12 \%$ fruit set at $24^{\circ} \mathrm{C}$ night temperature and $22.8 \%$ at $18^{\circ} \mathrm{C}$ night temperature. Again, at higher day temperature of $28^{\circ} \mathrm{C}$, they obtained $38.5 \%$ fruit set while at $25^{\circ} \mathrm{C}$ day temperature, they calculated $42.2 \%$ fruit set. Huberman et al. (1997) stated that high temperature reduced indole-3-acetic acid levels and particularly auxin transport capacity in the reproductive organs which ultimately induced reproductive organ abscission in pepper and in consequence reduced percent fruit set.

Number of fruits per plant : The different entries under investigation varied greatly in producing fruits per plant in both high and low temperature conditions (Table 1). The number of fruits produced per plant ranged from 1.67 to 21 being the lowest in the genotype SP01l and SP005 and the highest in SP002 at low temperature. SP003 and SP006 produced fruits per plant numbering around 2 only at low temperature condition. On the contrary, the genotypes SP002 and SP009 produced the maximum number of fruits per plant, 14.33 and 15.67, respectively, at $29 / 23^{\circ} \mathrm{C}$. Sanchez et al. (1993) obtained 6.6 to 12.4 fruits per plant in bell pepper under varied plant spacing. Rylski and Spigelman (1982) got the result that at higher night temperature of $24^{\circ} \mathrm{C}$ and lower night temperature of $18^{\circ} \mathrm{C}$, the number of fruits produced per plant were 6.6 and 12.6, respectively. It indicated that the lower night temperature of $18^{\circ} \mathrm{C}$ produced more number of fruits per plant, whereas, at higher day temperature of $28^{\circ} \mathrm{C}, 9.2$ fruits were produced per plant and at $25^{\circ} \mathrm{C}$ day temperature it was 10.1 .

Individual fruit weight : Individual fruit weight ranged from $7.44 \mathrm{~g}$ to $125.00 \mathrm{~g}$ (SP001 and SP012, respectively) at low temperature and $5.35 \mathrm{~g}$ to $103.80 \mathrm{~g}$ (SP00l and SP008, respectively) at $29 / 23^{\circ} \mathrm{C}$ temperature (Table 2). High temperature $29 / 23^{\circ} \mathrm{C}$ influenced the individual fruit weight and it was reduced compared to the fruits produced at low temperature. Rylski and Spigelman (1986b) obtained $145 \mathrm{~g}$ per fruit weight in open field and $175 \mathrm{~g}$ in the screen house during winter season in hot inland areas of Israel. Wien and Zhang (1991) obtained individual fruit weight ranging from $15.9 \mathrm{~g}$ to $24.3 \mathrm{~g}$ in Shamrock Bell pepper under higher temperature of $27 / 21^{\circ} \mathrm{C}$ (day/night). Bakker (1989) found higher individual fruit weight of 119.7 to $1319 \mathrm{~g}$ under different humidity levels grown at $23 / 18^{\circ} \mathrm{C}$ (day/night) temperature. 
Table 1. Percent fruit set, number of fruits per plant and individual fruit weight (g) of 12 sweet pepper genotypes at different temperature regimes grown at AVRDC, Taiwan during 1999-2000.

\begin{tabular}{|c|c|c|c|c|c|c|}
\hline \multirow[t]{2}{*}{ Genotypes } & \multicolumn{2}{|c|}{$\begin{array}{l}\text { \% Fruit set at } \\
\text { temperature }\end{array}$} & \multicolumn{2}{|c|}{$\begin{array}{l}\text { Number of fruits per } \\
\text { plant at temperature }\end{array}$} & \multicolumn{2}{|c|}{$\begin{array}{l}\text { Individual fruit weight } \\
\text { (g) at temperature }\end{array}$} \\
\hline & $24 / 18^{\circ} \mathrm{C}$ & $29 / 23^{\circ} \mathrm{C}$ & $24 / 18^{\circ} \mathrm{C}$ & $29 / 23^{\circ} \mathrm{C}$ & $24 / 18^{\circ} \mathrm{C}$ & $29 / 23^{\circ} \mathrm{C}$ \\
\hline SP001 & 30.25b-e & $24.25 c$ & $7.44 \mathrm{c}$ & $5.35 f$ & $17.00 \mathrm{~b}$ & $5.33 \mathrm{~b}$ \\
\hline SP002 & 56.17a & 48.86a & $11.62 \mathrm{c}$ & $9.31 \mathrm{f}$ & $21.00 \mathrm{a}$ & 14.33a \\
\hline SP003 & $17.75 \mathrm{fg}$ & 15.55de & $66.58 b$ & 42.24de & 2.00cd & 4.33bc \\
\hline SP004 & 31.73bcd & $25.19 c$ & $69.95 b$ & 37.87de & 3.33cd & $2.00 \mathrm{c}$ \\
\hline 5P005 & 22.2efg & $12.50 \mathrm{e}$ & 48.11b & $64.92 \mathrm{c}$ & $1.67 d$ & $3.00 \mathrm{bc}$ \\
\hline SP006 & $24.25 c-f$ & $28.15 c$ & $72.38 b$ & 42.76de & 2.33cd & 4.33bc \\
\hline SP007 & 33.85b & $39.25 b$ & $60.22 b$ & 49.00d & 3.33cd & $5.00 \mathrm{~b}$ \\
\hline SP008 & 25.35b-f & $24.33 c$ & $68.30 \mathrm{~b}$ & 103.80a & 3.67cd & $4.67 b$ \\
\hline SP009 & $55.29 a$ & $24.67 \mathrm{c}$ & $68.08 \mathrm{~b}$ & $35.94 \mathrm{e}$ & 3.33cd & 15.67a \\
\hline SP010 & $32.50 \mathrm{bc}$ & $21.87 \mathrm{~cd}$ & 75.93b & 40.12de & $4.33 c$ & $5.00 \mathrm{~b}$ \\
\hline SP01l & $14.63 g$ & $10.47 \mathrm{e}$ & 109.80a & 81.64b & $1.67 d$ & $4.00 \mathrm{bc}$ \\
\hline SP012 & 24.40 def & $12.69 \mathrm{e}$ & $125.00 \mathrm{a}$ & $69.27 \mathrm{c}$ & $3.67 \mathrm{~cd}$ & $2.67 \mathrm{bc}$ \\
\hline $\begin{array}{l}\text { Level of } \\
\text { significance }\end{array}$ & $* *$ & $* *$ & $* *$ & $* *$ & $* *$ & $* *$ \\
\hline CV (\%) & 15.39 & 15.97 & 29.49 & 12.90 & 24.11 & 23.37 \\
\hline
\end{tabular}

In a column, means followed by common letters are not significantly different from each other at $1 \%$ of level of probability by DMRT.

Individual fruit weight : Individual fruit weight ranged from $7.44 \mathrm{~g}$ to $125.00 \mathrm{~g}$ (SP001 and SP012, respectively) at low temperature and $5.35 \mathrm{~g}$ to $103.80 \mathrm{~g}$ (SP00l and SP008, respectively) at $29 / 23^{\circ} \mathrm{C}$ temperature (Table 2). High temperature $29 / 23^{\circ} \mathrm{C}$ influenced the individual fruit weight and it was reduced compared to the fruits produced at low temperature. Rylski and Spigelman (1986b) obtained $145 \mathrm{~g}$ per fruit weight in open field and $175 \mathrm{~g}$ in the screen house during winter season in hot inland areas of Israel. Wien and Zhang (1991) obtained individual fruit weight ranging from $15.9 \mathrm{~g}$ to $24.3 \mathrm{~g}$ in Shamrock Bell pepper under higher temperature of $27 / 21^{\circ} \mathrm{C}$ (day/night). Bakker (1989) found higher individual fruit weight of 119.7 to $1319 \mathrm{~g}$ under different humidity levels grown at $23 / 18^{\circ} \mathrm{C}$ (day/night) temperature.

Yield per plant : Variation was also found regarding per plant yield among the genotypes grown under both $24 / 18^{\circ} \mathrm{C}$ and $29 / 23^{\circ} \mathrm{C}$. The highest per plant yield was achieved by the genotype SP009 $(242.50 \mathrm{~g})$ at low temperature and the same genotype also gave the highest per plant yield at higher temperature but the yield 
at the later situation was near about double than lower temperature (Table 2). The genotypes SP001, SP002, SP004, and 5P012 showed the lower performance pertaining to per plant yield compared to the other genotypes. It was also found that the total yield per plant in most of the genotypes was higher at higher temperature than that of the low temperature. Cochran (1932) obtained per plant yield under warm condition ranging from $10.0 \mathrm{~g}$ to $795 \mathrm{~g}$. The range being very high compared to the present investigation. But when Cochran studied under normal day length condition, yield varied from $65.9 \mathrm{~g}$ to $803.3 \mathrm{~g}$ which was also very high. This high yield might be due to the differences in the genotypes as well as variation in other environmental conditions.

Table 2. Yield/plant (g), fruit length $(\mathrm{mm})$ and fruit diameter $(\mathrm{mm})$ of 12 sweet pepper genotypes at different temperature regimes grown at AVRDC, Taiwan during 1999-2000.

\begin{tabular}{|c|c|c|c|c|c|c|}
\hline \multirow[t]{2}{*}{ Genotypes } & \multicolumn{2}{|c|}{$\begin{array}{l}\text { Yield/plant (g) at } \\
\text { temperature }\end{array}$} & \multicolumn{2}{|c|}{$\begin{array}{l}\text { Fruit length }(\mathrm{mm}) \text { at } \\
\text { temperature }\end{array}$} & \multicolumn{2}{|c|}{$\begin{array}{l}\text { Fruit diameter }(\mathrm{mm}) \text { at } \\
\text { temperature }\end{array}$} \\
\hline & $24 / 18^{\circ} \mathrm{C}$ & $29 / 23^{\circ} \mathrm{C}$ & $24 / 18^{\circ} \mathrm{C}$ & $29 / 23^{\circ} \mathrm{C}$ & $24 / 18^{\circ} \mathrm{C}$ & $29 / 23^{\circ} \mathrm{C}$ \\
\hline SP00l & $82.33 \mathrm{~h}$ & $31.05 \mathrm{e}$ & $59.47 f$ & $49.01 \mathrm{e}$ & $23.16 f$ & 18.63d \\
\hline SP002 & $136.70 \mathrm{~d}$ & 56.83de & $67.74 \mathrm{ef}$ & $56.07 \mathrm{de}$ & $28.00 \mathrm{e}$ & $26.35 c$ \\
\hline SP003 & 106.10efg & 124.70b-e & 81.24be & $71.45 c$ & $52.32 \mathrm{c}$ & $38.98 \mathrm{~b}$ \\
\hline SP004 & $117.90 \mathrm{e}$ & 52.56de & $84.87 \mathrm{~b}$ & $82.95 b$ & $52.96 \mathrm{c}$ & $41.30 \mathrm{~b}$ \\
\hline SP005 & 79.94h & 93.17cde & 66.04def & $48.48 \mathrm{e}$ & $46.08 \mathrm{~d}$ & $42.34 \mathrm{~b}$ \\
\hline SP006 & 92.38gh & $145.70 \mathrm{bcd}$ & 69.10de & $49.69 \mathrm{e}$ & $51.50 \mathrm{c}$ & $48.45 a$ \\
\hline SP007 & 97.92fg & $170.00 \mathrm{bc}$ & $60.88 \mathrm{ef}$ & 56.18de & $58.18 b$ & $53.44 \mathrm{a}$ \\
\hline SP008 & $111.50 \mathrm{ef}$ & $161.50 \mathrm{bc}$ & $78.38 \mathrm{bc}$ & 68.65 c & $56.21 \mathrm{bc}$ & $50.77 a$ \\
\hline SP009 & $242.50 \mathrm{a}$ & $437.00 \mathrm{a}$ & $121.30 \mathrm{a}$ & 110.90a & $45.08 \mathrm{~d}$ & $39.72 b$ \\
\hline SP010 & $118.10 \mathrm{e}$ & 219.30b & 67.29def & $59.47 d$ & $58.76 \mathrm{~b}$ & $50.17 \mathrm{a}$ \\
\hline SP01l & $187.70 \mathrm{c}$ & 189.10bc & 73.00cd & $67.20 \mathrm{c}$ & $65.97 a$ & $40.83 b$ \\
\hline SP012 & $227.30 \mathrm{~b}$ & 106.50cde & 74.27cd & $63.64 \mathrm{~cd}$ & $58.59 \mathrm{~b}$ & 53.29a \\
\hline $\begin{array}{l}\text { Level of } \\
\text { significance }\end{array}$ & $* *$ & $* *$ & $* *$ & $* *$ & $* *$ & $* *$ \\
\hline CV(\%) & 6.51 & 32.54 & 6.69 & 6.65 & 5.65 & 6.58 \\
\hline
\end{tabular}

In a column, means followed by common letters are not significantly different from each other at $1 \%$ level of probability by DMRT.

Fruit length : The length of fruit was highly influenced by the high and low temperatures. It was also observed the fruit size reduced remarkably due to high temperature (Table 2). The maximum fruit length $(121.30 \mathrm{~mm})$ was measured in SP009 at low temperature, while the lowest in SP001 (59.47 $\mathrm{mm})$. The genotype SP009 gave the highest fruit length at higher temperature 
also and the genotype SP00l $(49.01 \mathrm{~mm})$ also gave the least fruit length when grown under low temperature condition. The fruit length of sweet pepper was $92.00 \mathrm{~mm}$ under screen house and $87.00 \mathrm{~mm}$ in the open field (Ryiski and Spigelman, 1986b). Fruit weight, length, and width were the greatest at the temperature of $25 / 18^{\circ} \mathrm{C}$ (day/night), which is in agreement with the present findings (Ali and Kelly, 1982).

Fruit diameter: Fruit diameter ranged from $23.16 \mathrm{~mm}$ to $65.97 \mathrm{~mm}$ in SP00l and SP01l, respectively, under low temperature condition. (Table 2). Under high temperature condition, SP007 produced fruits with the highest diameter (50.77 $\mathrm{mm})$. SP00l showed the lowest fruit diameter $(71.00 \mathrm{~mm})$ in screen house (Ryiski and Spigelman, 1986a) and $67.00 \mathrm{~mm}$ under the open field condition.

Proline content in leaves : Under lower temperature of $24 / 18^{\circ} \mathrm{C}$, the genotypes SP002 produced the higher amount of proline $(0.22 \mu \mathrm{mol} / \mathrm{g} \mathrm{FW})$ and it was superior to other accessions. Marked variation was observed on the production of leaf proline under high temperature condition $\left(29 / 23^{\circ} \mathrm{C}\right)$. The genotype SP009 had the higher proline content $(0.09 \mu \mathrm{mol} / \mathrm{g} \mathrm{FW})$ under high temperature condition,

Table 3. Proline content of leaves of 12 sweet pepper genotypes under two different temperature regimes grown at AVRDC, Taiwan during 1999-2000.

\begin{tabular}{lll}
\hline \multirow{2}{*}{ Genotypes } & \multicolumn{2}{c}{ Proline content of leaves $(\mu \mathrm{mol} / \mathrm{g} \mathrm{FW})$ at temperature } \\
\cline { 2 - 3 } $24 / 18^{\circ} \mathrm{C}$ & \multicolumn{1}{c}{$29 / 23^{\circ} \mathrm{C}$} \\
\hline SP001 & $0.12 \mathrm{~b}$ & $0.06 \mathrm{fgh}$ \\
SP002 & $0.22 \mathrm{a}$ & $0.03 \mathrm{~h}$ \\
SP003 & $0.05 \mathrm{~d}$ & $0.11 \mathrm{bcd}$ \\
SP004 & $0.09 \mathrm{cde}$ & $0.04 \mathrm{gh}$ \\
SP005 & $0.05 \mathrm{e}$ & $0.07 \mathrm{efg}$ \\
SP006 & $0.04 \mathrm{ef}$ & $0.13 \mathrm{abc}$ \\
SP007 & $0.03 \mathrm{f}$ & $0.08 \mathrm{c}-\mathrm{f}$ \\
SP008 & $0.04 \mathrm{ef}$ & $0.14 \mathrm{ab}$ \\
SP009 & $0.03 \mathrm{f}$ & $0.16 \mathrm{a}$ \\
SP010 & $0.06 \mathrm{~d}$ & $0.10 \mathrm{de}$ \\
SP011 & $0.05 \mathrm{~d}$ & $0.07 \mathrm{efg}$ \\
SP012 & $0.09 \mathrm{cde}$ & $0.07 \mathrm{efg}$ \\
\hline Level of significance & $* *$ & $* *$ \\
CV (\%) & 18.37 & 15.97 \\
\hline
\end{tabular}

In a column, means followed by common letters are not significantly different from each other at $1 \%$ of level of probability by DMRT. 
which was statistically at par with the genotypes SP006 and SP008. Proline content of the sensitive genotypes decreased under high temperature conditions compared to low temperature and the heat tolerant variety produced higher quantity of proline in leaf under high temperature conditions. Thus, from the Table 3, it seemed that the four lines viz., SP00l, SP002, SP003, and SP012 were not heat tolerant, which is in consonance with the categorization of the genotypes pertaining to the traits investigation data. Kuo et al. (1986) studied the leaf proline content of tomato under high temperature condition and they found that under high temperature condition, proline content increases as has been reflected in this investigation.

\section{Conclusion}

On the basis of the results of the experiment, it may be concluded that percent fruit-set and fruit size in plants raised at $24 / 18^{\circ} \mathrm{C}$ was higher than at $29^{\circ} / 23^{\circ} \mathrm{C}$. Yield per plant was higher at $29 / 23^{\circ} \mathrm{C}$ than $24 / 18^{\circ} \mathrm{C}$. Eight genotypes, namely SP003, SP005, SP006, SP007, SP008, SP009, SP010, and SP01l were found to be heat tolerant and the rest four were heat sensitive. Proline content in heat tolerant genotypes was comparatively high than the sensitive ones. Based on the investigations, SP006, SP007, SP008, SP009, SP010, and SP011 may be recommended as heat tolerant genotypes to proceed on for varietal development of sweet pepper in Bangladesh.

\section{References}

Ali, A.M. and W.C. Kelly. 1982. Effect of the early growing termperature on the fruit size and shape of sweet peppers (Capsicum annuum L.). Int'l Hort. Congress. Abs. p. 1562.

Bakker, J. C. and J.A.M. Van Uffelen. 1998. The effects of diurnal temperature regimes on growth and yield of sweet pepper. Netherlands J. Agril. Sci. 36: 20 1-208.

Bakker, J.C. 1989. The effects of air humidity on flowering, fruit set, seed set and fruit growth of glasshouse sweet pepper (Capsicum annuum L.). Scientia Hort. 40: 1-8.

Berke, T.G., L.L. Black, S. K. Green, R. A. Morris, N. S. Talekar and J.F. Wang. 1999. Suggested Cultural Practices for field cultivation of sweet peppers. Intl. Cooperator's Guide. AVRDC. Pub. No. 99-497. AVRDC. P.O. Box 42, Shanhua, Taiwan 741, ROC.

Cochran, H.L. 1932. Factors affecting flowering and fruit setting in the pepper. Proc. Amer. Soc. Hort. Sci. 09: 434-437.

Cochran, H.L. 1936. Some factors influencing growth and fruit setting in the pepper. Cornell Agr. Expt. Sta. Memoir. No. 190. p. 36.

Dorland, R.E. and, F.W. Went.1947. Plant growth and controlled condition viii. Growth and fruiting of chilli peppers (C. annuum). Amer. J. Bot. 34: 393-401. 
Gomez, K. A. and A. A. Gomez. 1984. Statistical Producers of Agricultural Research. John Willey and Sons Publication, New York. pp. 20-215.

Huberman, M., J. Riov, B. Aloni and R. Goren.1997. Role of ethylene biosynthesis and auxin content and transport in high temperature-induced Abscission of pepper reproductive organs. J. Plant Growth Regul. 16:129-135.

Kuo, C.G., H.M. Chen, and L.H. Ma. 1986. Effect of high temperature on proline content in tomato floral buds and leaves. J. Amer. Soc. Hort. Sci. 111: 734-750.

Ryiski, I. and M. Spigelman. 1982. Effects of different diurnal temperature combination on fruit set of sweet pepper. Scientia Hort. 17: 101-106.

Ryiski, I. and M. Spigelman. 1986a. Use of shading to control the time of harvest of redripe pepper fruits during the winter season in a high-radiation dessert climate. Scientia Hort. 29: 37-45.

Ryiski, I. and M. Spigelman. 1986b. Effect of shading on plant development, yield and fruit quality of sweet pepper grown under conditions of high temperature and radiation. Scientia Hort. 29: 31-35.

Sanchez, V.M., F.J. Sundstrom and N.S. Lang. 1993. Plant size influences-Bell pepper seed quality and yield. Hort. Sci. 28(8):809-811.

Song, K.W., S.K. Park and C.K. Kim. 1976. Studies on the flower abscission of hot pepper. Res. Rept. Office Rural Dev. 18: 9-32.

Troll, W. and J. Lindsley. 1955. A photometric method for the determination of proline. J. Biol. Chem. 215: 655-660.

Wien, H.C. and Y. Zhang. 1991. Prevention of flower abscission in bell pepper. J. Amer Soc. Hort. Sci. 116(3): 516-519. 